\title{
Lanthanides oxides usage to increase radiopaque of bioactive ceramics
}

\author{
O.Dubok, O.Shynkaruk ${ }^{*}$, E.Buzaneva \\ National T.Shevchenko University of Kyiv, \\ 64 Volodymyrska Str., 01601 Kyiv, Ukraine \\ *Institute for Problems of Material Science, National Academy of Sciences \\ of Ukraine, 3 Kryzhanivskogo Str., 03142 Kyiv, Ukraine
}

Received November 20, 2012

\begin{abstract}
In order to increase the value of radiopaque while preserving the unique biological properties of bioactive ceramics and composites based on calcium phosphates, bioglasses and glass-ceramics used for bone repair, the different kinds of doping have been analyzed. By modified method of chemical precipitation the samples of doped hydroxyapatite (HAP) were manufactured with 1 and $3 \%$ calcium atoms substituted by ytterbium, as well as similarly doped bioactive glass and glass-ceramics. The size of the elementary crystals in the doped HAP is almost twice less than in undoped one (respectively 13 and $25 \mathrm{~nm}$ ). By IR, XPS and XRD methods the structure of the doped HAP have been studied as well as valence state of ytterbium in it. The results revealed formation of homogeneous solid solutions of HAP with ytterbium, where ytterbium ions occupy position of calcium in the apatite crystal lattice being mainly in the trivalent state as $\mathrm{Yb}^{3+}$. Radiographs obtained using a typical medical X-ray equipment, confirmed that doping even with $1 \%$ ytterbium significantly increases the radiopaque of the ceramic implants made of HAP. Doping with lanthanide oxides may also significantly improve other properties of bioactive ceramics which are important for their use in medicine and biology.
\end{abstract}

С целью увеличения рентгеноконтрастности при сохранении уникальных биологических свойств биоактивной керамики и композитов на основе фосфатов кальция, биостекла и биоситаллов, используемых для восстановления костей, проанализированы различные типы легирования этой керамики. На основе модифицированного метода химического соосаждения гидроксиапатита (ГАП) получены образцы ГАП, в которых 1 и $3 \%$ атомов кальция замещены иттербием, а также аналогично легированные биоактивное стекло и биоситалл. Размер элементарных кристаллов в легированном ГАП почти вдвое меньше чем в нелегированном (соответственно 13 и 25 нм). Методами IR, XPS и XRD исследованы структура легированного ГАП и валентное состояние иттербия в нем. Полученные результаты свидетельствуют об образовании однородных твердых растворов ГАП с иттербием, который занимает в ГАП позицию кальция, причем ионы иттербия встраиваются в кристаллическую решетку апатита преимущественно в трехвалентном состоянии как $\mathrm{Yb}^{3+}$. Рентгенограммы, полученные с помощью типовой медицинской рентгеновской аппаратуры, подтвердили, что легирование даже 1 \% иттербия заметно увеличивает рентгеноконтрастность имплантатов из ГАП. Легирование оксидами лантаноидов может также существенно улучшить другие свойства биоактивных керамик.

\section{Introduction}

Bioactive ceramics based on calcium phosphates, bioglasses and bioglass-ceramics confidently have gained the position of key materials for bone tissue remodeling in the modern medicine. They are also rapidly expanding their usage in drug delivery systems, gene engineering and gene therapy, as 
well as in other fields of medicine and biology [1]. In fact, nanoparticles of the bioactive ceramics can be used as a window created by nature for a dialogue with the inner world of living organisms, testing, correction and restoration of many physiological processes in organisms and it is obvious that in this field we should expect much more important results. Therefore, it is important to study a functionalization of bioactive ceramics i.e. the ways of their targeted modification in order to impart them the new specific physical-chemical and biological properties, which greatly expand usage of the bioactive materials. In particular, from the point of view of X-ray methods, calcium phosphates' lack of radiopacity is one of its drawbacks. The main advantage of bioactive ceramics - the similarity of its chemical composition to the bone's biominerals in this sense is turned into disadvantage because after filling bone defect the synthetic calcium phosphate is poorly distinguishable from the bone at the bone radiographs and the bone remodelling processes cannot be controlled by X-ray methods. Due to this reason, the bone remodeling is controlled by biopsies, which is quite traumatic and painful for patients.

Similar drawbacks of the bioactive ceramics have been also revealed in the usage of fluorescent, EPR and NMR control of the bioceramics behavior in living body, in neutron capture therapy with the bioceramics etc.

The ways of the bioactive ceramics properties modification in order to enhance radiopacity cannot be considered as satisfactory.

Increase of radiopacity is based on fundamental physical laws of X-rays absorption, which implies that X-rays absorption coefficient $(\tau)$ depends on the atomic number of the dopant $(Z)$ and the wavelength $(\lambda)$ of X-rays:

$$
\tau=k \rho Z^{3} \lambda^{3}
$$

where $k$ - coefficient, $\rho-$ density. For the fixed measurement conditions $(\lambda=$ const $)$ and the fixed substance density (densities of all selected bioceramics are similar) the absorption coefficient $\tau$ is proportional to $Z^{3}$. For a chemical compound, the total absorption coefficient is equal to the sum of the absorption coefficients of atoms that make up the substance. Roughly it can be assumed that the increase in the absorption coefficient of doped ceramics is expressed by the formula

$$
\Delta \tau / \tau=1+m\left(\frac{z_{1}}{z_{2}}\right)^{3},
$$

where $m$ - atomic fraction of impurities, $Z_{1}$ and $Z_{2}$ - atomic numbers of impurities and the heaviest atom of the main substance respectively [2]. For bioactive ceramics it is extremely important to preserve its biological properties, i.e. physical and chemical properties and interactions of the material with an internal environment of the body.

For example, as a radiopaque additive, iodine $(Z=53)$ often have been used. The study of synthesis of iodinated HAP revealed that when ammonium iodide was added to a solution of calcium nitrate, iodine doped the apatite crystal, replacing the hydroxyl groups, but the properties of the doped apatite differed significantly from the CaHAP. Also, in order to increase radiopacity the doping with barium $(Z=56)$ or bismuth $(Z=83)$ has been used but these elements are highly toxic and it was impossible to add them into bioresorbable ceramics. One of the most promising options is use of cesium $(Z=55)$, which can partially substitute sodium in the bioglasses or doped HAP. Cesium is the typical trace element in plants and animals. However, an instability of compounds of this element and their high volatility should be taken into account. Analysis of other alternatives has shown that some of lanthanide elements, especially those that can be divalent and are chemical analogues of calcium - samarium $(Z=62)$, and ytterbium $(Z=70)$ are most promising and effective in order to increase the radiopacity of calcium phosphates. Calculations by formula (2) show that doping with 2.3 at. $\%$ of ytterbium results in twofold increase in HAP radiopacity and it is quite clear that this result can be affected neither structural nor any other transformation of the material. Ytterbium like other lanthanides can be easy embedded in apatite crystal and therefore is a common impurity in minerals with this structure, due to the proximity of their ionic radii and electronegativity with calcium, which is essential for the formation of solid solutions of the substitution. Biocompatibility and valuable biological properties of ytterbium and other lanthanides were proved by their use in drugs to regulate blood clotting, wound healing, etc. Ytterbium, like all other lan- 
thanides can also be used for the doping bioglass and bioglass-ceramics. Increase of the radiopaque of the doped bioglasses and bioceramics is strictly the same as for HAP.

A comparative study of the biological properties of pure and itterbium doped HAP, bioactive glasses and glass-ceramics by method of cell culture revealed complete identity of results for doped and undoped ones. Thus doping with lanthanides preserves biological properties of the bioactive ceramics and allows to control their resorption processes by X-ray methods, without biopsies.

Presented arguments justify prospects to study ways to increase radiopaque of bioactive ceramics by doping it with some lanthanide oxides. In particular, ytterbium is the most suitable for such application as $\mathrm{Yb}^{2+}$ ion is quite similar to calcium ion.

HAP, bioactive glass and bioactive glassceramics selected for doping have been currently used in the medicine in Ukraine. Their main application is to fill bone defects and promote the restoration of the bone tissue in various fields of surgery. Doped bioactive ceramics with increased radiopaque can improve the efficiency of such application due to control of the biotransformation of such material in the body without biopsy surgery.

It should be noted that doping with special combinations of lanthanides can also significantly improve the luminescent, magnetic and nuclear properties of the bioactive ceramics and therefore is useful for functionalization of other applications of the bioactive ceramics.

\section{Experimental procedure}

\subsection{Sample preparation}

Samples of pure HAP, labeled as HAP1, were synthesized by precipitation from aqueous solution of calcium nitrate and ammonium phosphate at $\mathrm{pH}=10-12$, followed by aging for $72 \mathrm{~h}$ at room temperature $\left(22^{\circ} \mathrm{C}\right)$, with further washing, filtration and drying. These samples were used as controls.

To substitute $1 \%$ and $3 \%$ of calcium atoms by ytterbium, in order to obtain the most uniform product, the modified precipitation method was used: the ytterbium oxide and the above initial salts were dissolved in minimal quantity of nitric acid. Then this solution has been added dropwise to alkaline ammonia hydroxide solution during vigorous stirring. The pure HAP
(HAP2) has been also prepared by this method.

Bioactive glass and bioglass-ceramics have been prepared by thorough mixing and grinding of dry initial salts followed by melting in a platinum crucible. Doping of the bioactive glass and bioglass-ceramics has been achieved by adding ytterbium nitrate solution into the mixture of the initial salts, then drying and melting.

\subsection{Studying methods}

FTIR. Functional groups available in the prepared powders were identified by FTIR (Thermo Nicolet NEXUS). The powders were mixed and ground with potassium bromide with the ratio of $1: 10$. The spectrum was measured in the range of 400 to $4000 \mathrm{~cm}^{-1}$ with resolution of $4 \mathrm{~cm}^{-1}$ and the number of scans of 50 .

XPS. X-ray photoelectron spectra were measured with photoelectron spectrometer JSPM-4610 (JEOL) using a non-monochromatic MgK $\alpha$ (1253.6 eV) X-ray source. Vacuum in the analysis chamber was $10^{-7} \mathrm{~Pa}$, the accuracy of the electron binding energy measurement was $0.1 \mathrm{eV}$. To neutralize the charge accumulating at insulating sample during the experiment, its surface has been coated with a thin layer of gold. To calibrate the X-ray photoelectron spectra the binding energy of Au $4 f$ energy levels has been used, thus providing a sufficiently high accuracy of the binding energies measurement for the elements of the samples.

XRD. The phase compositions of the samples were studied by X-ray diffraction with DRON-3M diffractometer, using CuK $\alpha$ radiation at the wavelength of $1.5418 \AA$ in $2 \theta$ range of $20-50^{\circ}$ with a step size of $0.1^{\circ}$ and measuring time of 4 seconds per step.

Specific surface. Specific surface areas of the synthesized powders were measured by the BET method at the facility of Frantsevich Institute for Problems of Materials Science, Kyiv.

\section{Results and discussion}

The main objective of this study was to select such dopant that would provide maximal radiopacity and don't affect the unique biological properties of the selected materials. The results of X-ray diffraction study (XRD) of the synthesized HAP samples are presented in Fig. 1. They should be discussed within the framework of the known data that HAP powders produced by chemical precipitation have defected crystal 


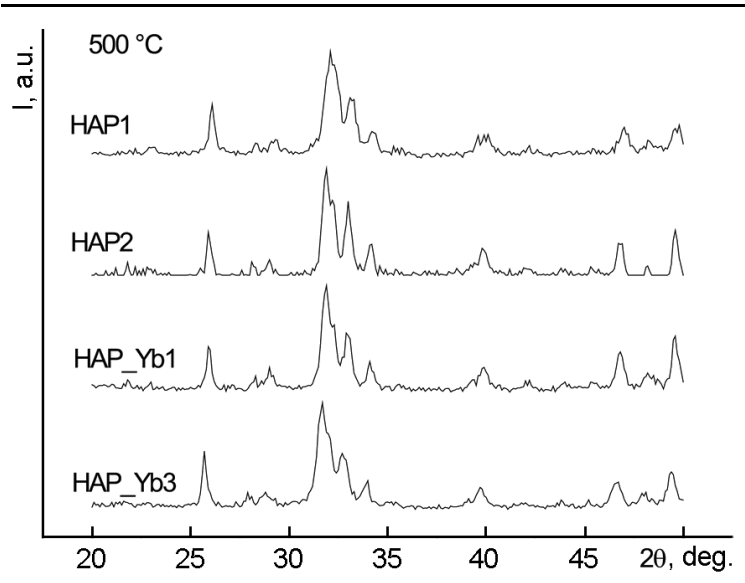

nied by loss of these impurities, gradual ordering and recrystallization of the nanocrystals.

The first stage of the ordering of HAP crystal structure (the loss of most of the water and components of the initial solution) ends approximately at $450-500^{\circ} \mathrm{C}$, although X-ray diffraction reflections remains broadened, thus reveals that defectness of the HAP are still significant. Defective HAP admits a significant deviation from stoichiometry, unlike the more perfect crystals, so during further calcination and ordering other phases may be separated, such as tricalcium phosphate [4]. Lost of carbonate groups in HAP occurs at $700-800^{\circ} \mathrm{C}$, i.e. the arrangement of the crystal structure of HAP is completed at $900-1000^{\circ} \mathrm{C}$ [4]. Therefore, to observe the transformations of the synthesized doped HAP all samples were calcined at $500^{\circ} \mathrm{C}$ and $1000^{\circ} \mathrm{C}$ for $1 \mathrm{~h}$. According to data presented in Fig. 1 all samples after synthesis and calcination at $500^{\circ} \mathrm{C}$ have crystal structure of defective HAP. Preservation of this structure and absence of lines of other phases after calcination at $1000^{\circ} \mathrm{C}$ while a significant narrowing of X-ray diffraction reflexes due to ordering of crystal structure reveal stoichiometry and thermal stability of the synthesized product. Comparison of different methods of the synthesis testifies that the method of "acid synthesis" used in this study, which is more suitable to produce homogeneous solid solutions, permits to produce the same pure and perfect unalloyed HAP, as commonly used method of salts co-precipitation. But after calcination at $1000^{\circ} \mathrm{C}$ in $\mathrm{HAP}$ samples doped with $3 \%$ of ytterbium, a new reflex with low intensity has appeared, which can be interpreted Calcination of the precipitate is accompa-
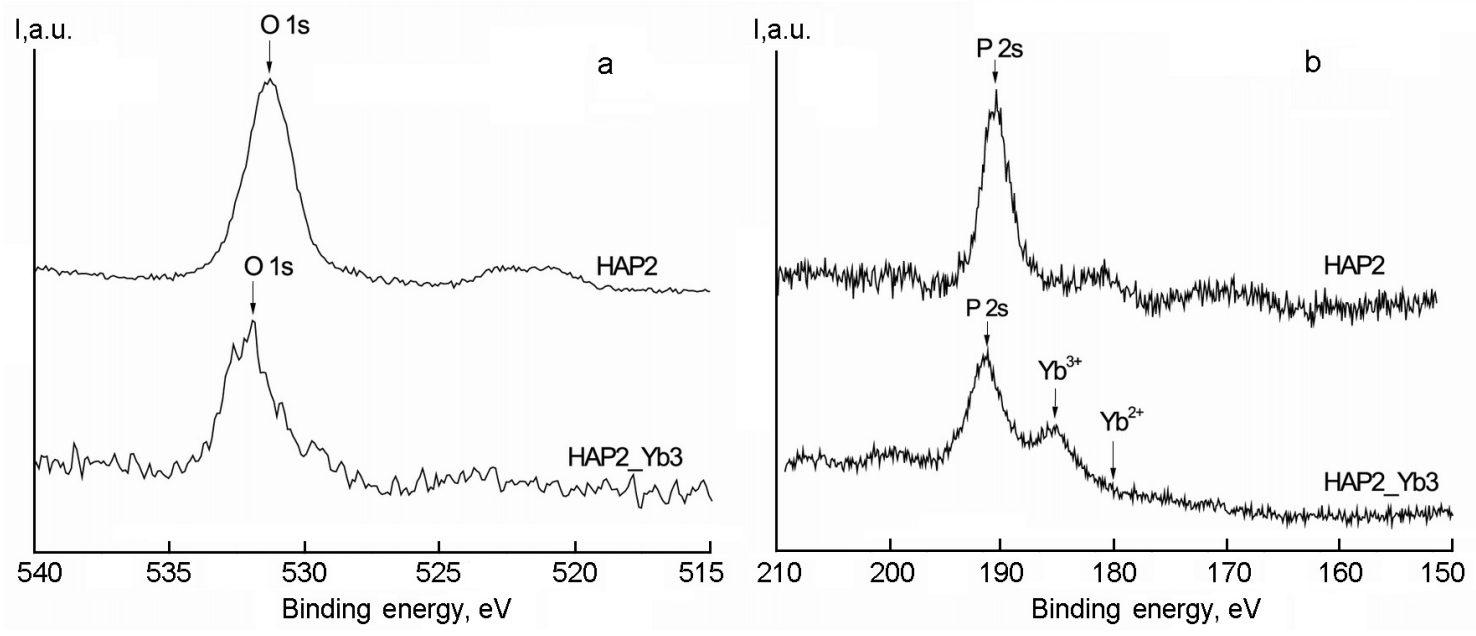

Fig. 2. XPS spectra of $\mathrm{O} 1 s$ (a) and $\mathrm{P} 2 s, \mathrm{Yb} 4 d$ (b) regions of HAP2 and HAP2_Yb3 samples. 
Table 1. Calculated lattice constants and deviations for Yb:HAP $\left(\mathrm{Ca}_{10-x} \mathrm{Yb}_{x}\left(\mathrm{PO}_{4}\right)_{6}(\mathrm{OH})_{2}\right)$ for different $x$ values $(0 \leq x \leq 0.03)$.

\begin{tabular}{|c|c|c|c|c||}
\hline Samples & $a=b /$ deviation $(\mathrm{nm})$ & $c /$ deviation $(\mathrm{nm})$ & $\begin{array}{c}\text { Calcination } \\
\text { temperature }\left({ }^{\circ} \mathrm{C}\right)\end{array}$ & $\begin{array}{c}\text { Doping } \\
\text { concentration }(\%)\end{array}$ \\
\hline JCPDS 9-0432 & 0.9418 & 0.6884 & & 0 \\
HAP1 & $0.9413 / 0,0005$ & $0.6833 / 0.0051$ & 500 & 0 \\
HAP2 & $0.9417 / 0.0001$ & $0.6884 / 0.0000$ & 500 & 1 \\
HAP_Yb1 & $0.9414 / 0.0004$ & $0.6877 / 0.0007$ & 500 & 3 \\
HAP_Yb3 & $0.9455 / 0.0037$ & $0.6909 / 0.0025$ & 500 & 0 \\
HAP1 & $0.9433 / 0.0015$ & $0.6885 / 0.0001$ & 1000 & 0 \\
HAP2 & $0.9409 / 0.0009$ & $0.6872 / 0.0012$ & 1000 & 1 \\
HAP_Yb1 & $0.9427 / 0.0009$ & $0.6885 / 0.0001$ & 1000 & 3 \\
HAP_Yb3 & $0.9434 / 0.0016$ & $0.6884 / 0.0000$ & 1000 & 0 \\
\hline
\end{tabular}

as tetracalcium phosphate phase $\mathrm{Ca}_{4}\left(\mathrm{PO}_{4}\right)_{2} \mathrm{O}$.

The appearance of this phase is the result of the fact that calculation of the initial chemicals quantity for synthesis of $\mathrm{Yb}$ doped HAP have suggested that $\mathrm{Yb}$ ion in solid solution with HAP should be doubly charged $\mathrm{Yb}^{2+}$. However, the XPS-spectra of the synthesized samples revealed (Fig. 2, b) that most of $\mathrm{Yb}$ ions remain triply charged. Thus the synthesized product contains an excess of calcium relative to HAP stoichiometry (which corresponds to the $\mathrm{Ca} / \mathrm{P}=1.67)$, and leads to the appearance of tetracalcium phosphate $\left(\mathrm{Ca}_{4}\left(\mathrm{PO}_{4}\right)_{2} \mathrm{O}\right.$ phase, for which the $\mathrm{Ca} / \mathrm{P}$ ratio equals 2 . When doping with $3 \%$ of $\mathrm{Yb}$ to balance the calcium excess the quantity of tetracalcium phosphate should be about $11 \%$ which is in good agreement with experimental data. It is well known that tetracalcium phosphate cannot be synthesized directly by coprecipitation and it is a result of transformation of defective HAP during calcination.

Table 1 shows the calculated unit-cell parameters of the samples. All the XRD diffractions of the samples can be well indexed as a hexagonal phase ( $P 63 / \mathrm{m}$ space group), agreeing well with the values of the standard data (JCPDS No.9-0432). The lattice parameters have not been modified significantly after substitution. All calculations have been performed using the Crystal Impact Match and UnitCell [5] software.

The results of the measurements of specific surface area for doped and pure HAP samples are presented in the Table 2. The data reveal nanosized structure of the synthesized powders as the specific surface area of $150 \mathrm{~m}^{2} / \mathrm{g}$ corresponds to particle size of $13 \mathrm{~nm}$ and $80 \mathrm{~m}^{2} / \mathrm{g}$ corresponds to
Table 2. Specific surface area of doped and pure HAP powders calcined at different temperatures

\begin{tabular}{|c|c|c||}
\hline$t,{ }^{\circ} \mathrm{C}$ & $\begin{array}{c}\text { Specific surface of } \\
\text { HAP with 0 \% Yb } \\
\left(\mathrm{m}^{2} / \mathrm{g}\right)\end{array}$ & $\begin{array}{c}\text { Specific surface of } \\
\text { HAP with 3 \% Yb } \\
\left(\mathrm{m}^{2} / \mathrm{g}\right)\end{array}$ \\
\hline 20 & 89.6 & 151.23 \\
500 & 62.61 & 127.15 \\
1000 & 6.05 & 22.23 \\
\hline
\end{tabular}

particle size of $25 \mathrm{~nm}$. The interesting feature of this data is the fact that the specific surface area of $\mathrm{Yb}$-doped HAP powder is about twofold bigger than the one of the undoped samples. This regularity can be explained by the appearance of particles of a second phase which inhibits recrystallization of the main HAP phase. This phenomenon can be used in technology and medicine.

XPS survey scans (Fig. 3) have identified oxygen, calcium, and phosphorus as the major constituents of HAP doped and undoped samples, as it had been expected [6]. The spectra of these samples have revealed the typical Auger resonance of $\mathrm{O}$ (KLL) orbital at $\sim 750 \mathrm{eV}$ and $\mathrm{Ca}(\mathrm{LMM}) \sim 970 \mathrm{eV}$. In the XPS spectrum of HAP and Yb-doped $\mathrm{HAP}$, the binding energies of $\mathrm{Ca}(2 p$, $348 \mathrm{eV}), \mathrm{O}(1 s, 532 \mathrm{eV})$, and $\mathrm{P}(2 p, 134 \mathrm{eV})$ can also be found. The binding energies of $\mathrm{Au} 4 f 7 / 2$ at 83.8 and $\mathrm{Au} 4 f 5 / 2$ at $87.45 \mathrm{eV}$ corresponding to the standard gold [7] were used for calibration and they do not hinder the interpretation of other parts of the spectrum. The difference in the background of Fig. $3 \mathrm{a}$ and $3 \mathrm{~b}$ is caused by inelastic scattering of photoelectrons, which is determined by working vacuum in the chamber during this experiment, by the parameters 

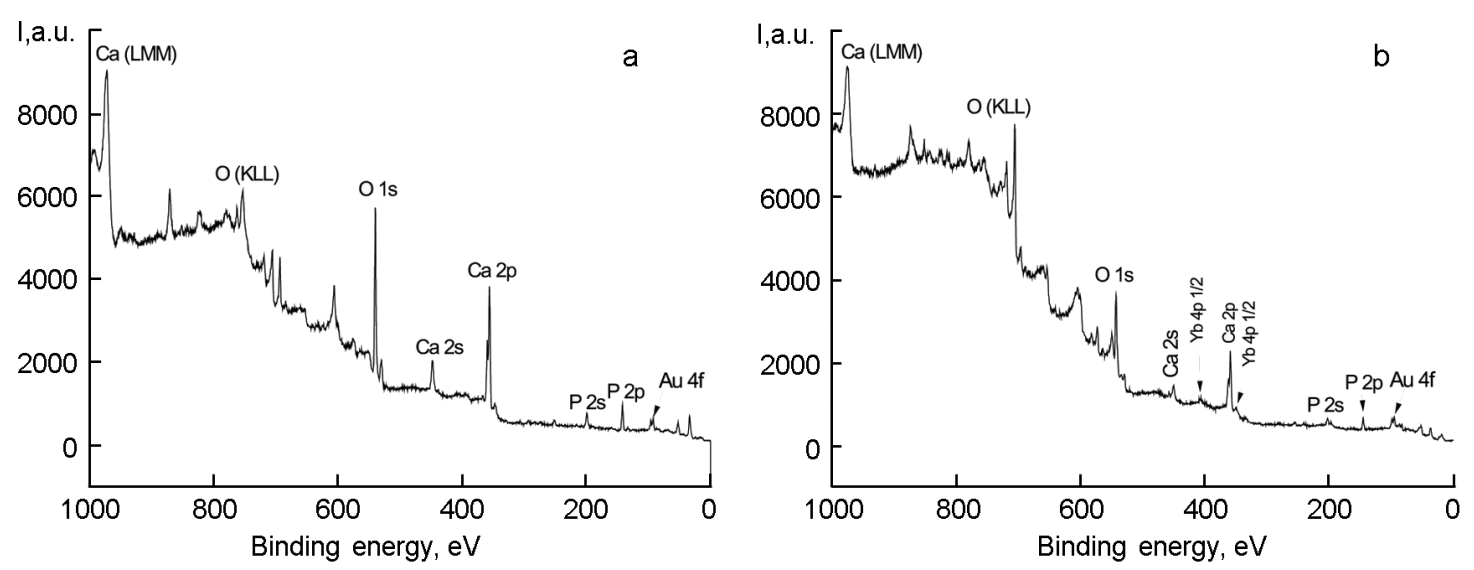

Fig. 3. XPS survey scan spectra of HAP2 (a) and HAP2_Yb3 (b) samples.

of the sample surface as well as some other factors that are poorly reproduced during each subsequent experiment and is uninformative for this discussion. The energy positions and details of individual peaks are better seen in the fragments near $P 2 s$ and $\mathrm{O} 1 \mathrm{~s}$ peaks of the same spectra presented in Fig. 2 with higher resolution. Draw attention the shift of peaks $\mathrm{P} 2 s$ and $\mathrm{O} 1 \mathrm{~s}$ in the direction of higher energies for the doped sample compared to undoped, which is about $1 \mathrm{eV}$. It can be explained by formation of solid solutions of HAP with ytterbium oxide, where the binding energy is larger than for HAP. The peak of $\mathrm{Yb}^{3+}(4 d$, $\sim 185 \mathrm{eV}$, Fig. 2, b) agrees well with the literature $[8,9]$, while the peak $\mathrm{Yb}^{2+}$ appears quite weak. Thus the XPS results provide the additional evidence for the successful HAP doping with ytterbium and reveal that the ytterbium ions enter into HAP structure mostly in the form of $\mathrm{Yb}^{3+}$. This also implies that the other lanthanides' ions that are stable only when they are triply charged also can be used to dope the HAP (that, by the way, comes from the composition of natural apatite minerals).

FTIR spectra of the HAP and HAP doped with $3 \%$ of $\mathrm{Yb}$, calcined at $500^{\circ} \mathrm{C}$ and $1000^{\circ} \mathrm{C}$ for 1 hour contain all the typical absorption bands or such spectra (Fig. 4). For example, for all the samples the fundamental vibration modes of $\mathrm{PO}_{4}{ }^{3-}$ are observed [10]. Very strong bands at $\sim 1092 \mathrm{~cm}^{-1}$ and $\sim 1036 \mathrm{~cm}^{-1}$ are associated with the triply degenerated $v_{3}$ antisymmetric stretching of $\mathrm{P}-\mathrm{O}$ band. The $962 \mathrm{~cm}^{-1}$ band can be attributed to the $v_{1}$ non-degenerated symmetric stretching of $\mathrm{P}-\mathrm{O}$ band. The bands at $604 \mathrm{~cm}^{-1}$ and $560-580 \mathrm{~cm}^{-1}$ can be attributed to the triply degenerated bending mode $v_{4}$ of $\mathrm{O}-\mathrm{P}-\mathrm{O}$ bond. The weak



Fig. 4. Diffuse reflectance infrared spectra of the pure HAP and HAP doped with $3 \%$ of $\mathrm{Yb}$ (calcined at 500 and $1000^{\circ} \mathrm{C}$ ).

band at $474 \mathrm{~cm}^{-1}$ is the component of the doubly degenerated bending mode, $v_{2}$, of the phosphate group. The characteristic bands of hydroxyl groups in apatite environment were observed at $3572 \mathrm{~cm}^{-1}$ and $\sim 633 \mathrm{~cm}^{-1}$ for all samples [11]. For all the samples the presence of stretching mode $\left(v_{s}\right)$ at $3572 \mathrm{~cm}^{-1}$ of the hydroxyl group can be noticed. The peak at $\sim 633 \mathrm{~cm}^{-1}$ is assigned to the librational mode $\left(v_{L}\right)$ of the hydroxyl group. The broad bands in the regions $3200-3600 \mathrm{~cm}^{-1}$ and $1600-1700 \mathrm{~cm}^{-1}$ in samples calcined at $500^{\circ} \mathrm{C}$ correspond to $\mathrm{H}-\mathrm{O}-\mathrm{H}$ bands of lattice water. The presence of $\mathrm{CO}_{3}{ }^{2-}$ groups could be noticed at the samples calcined at $500^{\circ} \mathrm{C}$. The bands at $1456-$ $1414 \mathrm{~cm}^{-1}$ correspond to the symmetric and antisymmetric stretching mode $v_{3}$ of carbonate group and the band at $879 \mathrm{~cm}^{-1}$ can be referred to the bending mode $v_{2}$ of carbonate group [12]. Thus, changes in the FTIR spectra due to calcination of the samples 


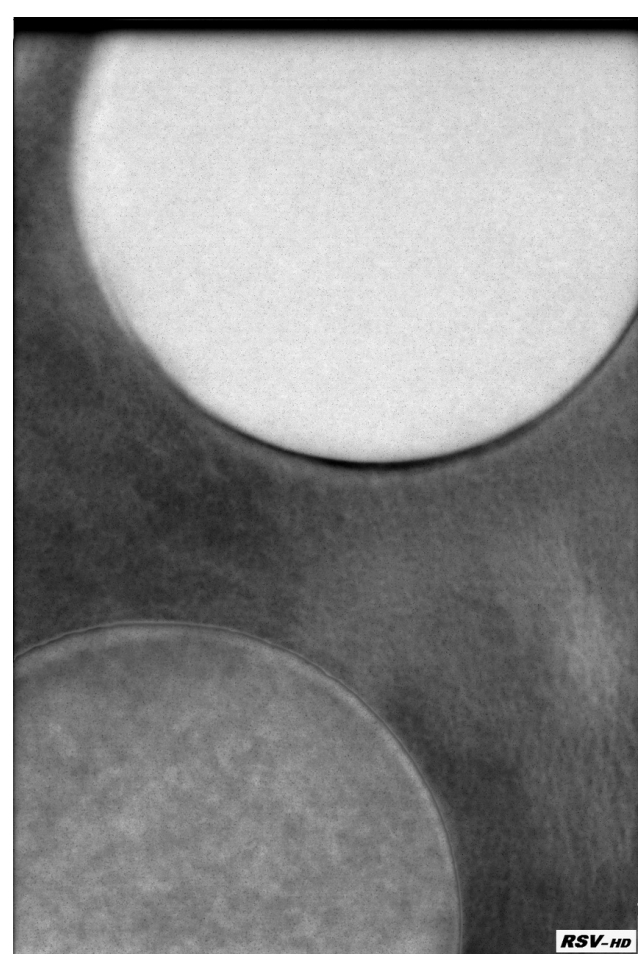

Fig. 5. Radiograph (negative, transmission) of animal bone with inserted implants of HAP and HAP doped with $1 \%$ of $\mathrm{Yb}$ reveals significant increase of radiopacity of doped HAP.

completely confirm the above concept on loss of the mother solution component and ordering of the HAP crystals with increasing temperature of thermal treatment.

To check radiopacity of the synthesized material two tablets of the same size (diameter $18 \mathrm{~mm}$ and height $6 \mathrm{~mm}$ ) made of HAP and HAP doped with $1 \%$ of $\mathrm{Yb}$ were inserted into the spongy animal bone. Radiograph (Fig. 5) was made with the typical high-resolution medical equipment — USB Radiology System (Visiodent) RSV-HD. It revealed a significant change of radiopacity of the doped sample, thus confirming the expected results of doping. The same results were obtained with the bioactive glasses and bioglass-ceramics in accordance with the fundamental laws of X-rays absorption. Thus even $1 \%$ of this impurity is sufficient to distinguish the implanted material against the bone, i.e. to control its biotransformation.

\section{Conclusions}

Therefore, this study confirmed prospects of synthesis of HAP solid solutions with lanthanides by the so-called "acid synthesis", which apparently provides greater homogeneity of the synthesized product. Doping HAP with ytterbium oxide results, according to XPS data, in embedding the impurity cation into the HAP crystal as $\mathrm{Yb}^{3+}$, with the unit cell parameters remaining almost unchanged. According to specific surface area measurements, the size of the primary nanocrystals in precipitate of the doped material $(13 \mathrm{~nm})$ is almost twice less than that of undoped $(25 \mathrm{~nm})$. When amount of the initial chemicals was calculated based on the model of HAP solid solution with divalent ytterbium the nonstoichiometric HAP have been synthesized which was decomposed on HAP and tetracalcium phosphate after calcination at $1000^{\circ} \mathrm{C}$. HAP as well as bioactive glasses and bioglass-ceramics doped with ytterbium always have increased radiopacity in accordance with the fundamental laws of X-rays absorption, and the introduction of even $1 \%$ of this impurity is sufficient to distinguish the implanted material against the bone, i.e. to control its biotransformation. Doping with lanthanides could be also promising for other applications of orthophosphate biomaterials.

Acknowledgements. This study was supported by National Academy of Sciences grants No.5.16.1.40, $108 \mathrm{H}$ and 4.11.39. We gratefully acknowledge the help of V.Karbivsky and N.Kurgan for XPS measurements and A.Bukov for XRD study.

\section{References}

1. M.Epple, K.Ganesan, R.Heumann, J.Mater. Chem., 20, 18 (2010).

2. J.H.Hubbell, Phys. Med.Biol., 44, 1 (1999).

3. S.Dorozhkin, Biomaterials, 2, 53 (2012).

4. A.P.Shpak, V.A.Dubok, V.L.Karbivski, Nanosystems, Nanomaterials., Nanotechnologies, $\mathbf{1}$, 1 (2003).

5. T.J.B.Holland, S.A.T.Redfern, Mineral.Mag., 61, 65 (1997).

6. Myung Chul Chang, Junzo Tanaka, Biomaterials, 23, 3879 (2002).

7. M.Abdulla-Al-Mamun, Y.Kusumoto, A.Mihata, Photochem.Photobiol.Sci., 8, 1125 (2009).

8. Dong Hak Kim, D.Lim, J.Korean Phys.Soc., 57, 1444 (2010).

9. Y.Ohno, J.Electron Spec.Rel.Phenom., 165, 1 (2008).

10. F.Frumosu, S.L.Iconaru, D.Predoi, Dig.J. Nanomater. Bios., 6, 1859 (2011).

11. C.S.Ciobanu, S.L.Iconaru, F.Massuyeau, $J$. Nanomater., 2012, 1 (2012).

12. C.S.Ciobanu, E.Andronescu, A.Stoicu, Dig. J. Nanomater. Bios., 6, 609 (2011). 


\title{
Використання оксидів лантаноїдів для збільшення рентгеноконтрастності біоактивних керамік
}

\author{
О.Дубок, О.Шинкарук, С.Бузаньова
}

\begin{abstract}
3 метою збільшення рентгеноконтрастності при збереженні унікальних біологічних властивостей біоактивної кераміки і композитів на основі фосфатів кальцію, біоскла та біоситалів, що використовуються для відновлення кісток, проаналізовано різні типи легування цієї кераміки. На основі модифікованого методу хімічного співосадження гідроксиапатиту (ГАП) отримано зразки ГАП, в яких 1 і $3 \%$ атомів кальцію заміщені ітербієм, а також аналогічно леговані біоактивне скло та біоситал. Розмір елементарних кристалів у легованому ГАП майже вдвічі менше, ніж у нелегованому (відповідно 13 та 25 нм). Методами IR, XPS и XRD досліджені структуру легованого ГАП i валентний стан ітербію у ньому. Отримані результати свідчать про утворення однорідних твердих розчинів ГАП з ітербієм, який займає у ГАП позицію кальцію, причому іони ітербію встроюються у кристалічну решітку апатиту переважно у тривалентному стані як $\mathrm{Yb}^{3+}$. Рентгенограми, отримані за допомогою типової медичної рентгенівської апаратури, підтвердили, що легування навіть 1 \% ітербію помітно збільшує рентгеноконтрастність імплантатів з ГАП. Легування оксидами лантаноїдів може також істотно поліпшити інші властивості біоактивних керамік, важливі для їх використання у медицині та біології.
\end{abstract}

